\title{
Soft Tissue Sarcoma of the Retroperitoneum Pathologic TNM Finding v8
}

National Cancer Institute

\section{Source}

National Cancer Institute. Soft Tissue Sarcoma of the Retroperitoneum Pathologic TNM Finding v8. NCI Thesaurus. Code C136797.

A pathologic finding about one or more characteristics of soft tissue sarcoma of the retroperitoneum, following the rules of the TNM AJCC v8 classification system. 